\title{
Preparation and in vivo evaluation of a newly developed bioglass ceramic
}

\author{
Feng-Huei Lin, Haw-Chang Liu, Ming-Hsiung Hon* and Cheng-Yi Wang \\ Center for Biomedical Engineering, College of Medicine, National Taiwan University, \\ Taipei, Taiwan, ROC; *Department of Material Sciences, National Cheng-Kung Univer- \\ sity, Tainan, Taiwan, ROC
}

Received November 1991, accepted December 1992

\begin{abstract}
This paper presents details of the fabrication of a glass ceramic, and its application as an artificial bone prosthetic material. This new bioglass ceramic, with composition of $\mathrm{Na}_{2} \mathrm{O} 8.4 \%, \mathrm{CaO} 40.6 \%, \mathrm{P}_{2} \mathrm{O}_{5} 12 \%$ and $\mathrm{SiO}_{2} 39 \%$, had 160-190MPa and 800-980 MPa of three-point bending strength and compressive strength respectively. The ceramic has a $(\mathrm{Na}, \mathrm{Ca})(\mathrm{P}, \mathrm{Si}) \mathrm{O}_{3}$ crystalline phase with a uniform crystal size of about $10 \mu \mathrm{m}$, which was attributed to the high nucleation frequency. The rabbit condyle test showed that the material formed a tight chemical bond with biological texture and had good biocompatibility.
\end{abstract}

Keywords: Bioglass ceramic, nucleation, bone graft

\section{INTRODUCTION}

To accelerate the healing of bone, or to enable it to heal at all, it is often necessary to fill it with a suitable substance. Autogenic tissue is considered to be the most suitable transplant material, because differences in histocompatibility and the risk of transferring a disease from one individual to another are nonexistent $t^{1,2}$. However, reconstructive surgery sometimes requires large amounts of transplant material, which may not be available in sufficient quantity, particularly from a diseased child. Also, autograft induces the risk of higher blood loss, damage to nerves and blood vessels, thrombosis and fracture of the donor site ${ }^{2,3}$. Therefore allografts and xenografts have been considered for bony tissue replacement. But these transplants may bring hazards to the patient because of the risk of infection (hepatitis, slow virus, bacterial contamination, AIDS, etc.) which limits their medical applications ${ }^{4,5,6}$.

The calcium phosphate system, in particular hydroxyapatite and tricalcium phosphate, has long been the subject of intensive investigation. However, their low mechanical strength restricts their application to the nonstress area of the skeleton ${ }^{7,8,9}$. Glass ceramics, which have been extensively studied, mainly by Hench ${ }^{10-12}$, Blencke ${ }^{13}$, Eulenberger ${ }^{14}$ and Ravel ${ }^{15}$, show an ability to form tight chemical bonds with living structures as well as high mechanical strength ${ }^{11-9} 4,16$.

Recently, the authors have investigated some bioglass ceramics in the system of $\mathrm{Na}_{2} \mathrm{O}-\mathrm{CaO}-$ $\mathrm{P}_{2} \mathrm{O}_{5} \mathrm{SiO}_{2}$ which revealed direct contact between the

Correspondence and reprint requests to: Dr Feng-Huei Lin (C) 1993 Butterworth-Heinemann for BES $0141-.5425 / 93 / 06481-06$ material and regenerated bone without an intermediate layer of connective tissue; the contact phase has a high mechanical strength. In our study, the preparation and fabrication of this new bioglass ceramic is described. The biocompatibility of the material was also investigated in vivo.

\section{EXPERIMENTAL PROCEDURES}

\section{Material preparation}

The batch mixture with nominal composition of $\mathrm{Na}_{2} \mathrm{O} 8.4 \%, \mathrm{CaO} 40.6 \%, \mathrm{P}_{2} \mathrm{O}_{5} 12 \%$ and $\mathrm{SiO}_{2} 39 \%$ in weight ratio was prepared from reagent grade chemicals of $\mathrm{Na}_{2} \mathrm{CO}_{3}, \mathrm{CaCO}_{3}, \mathrm{Ca}_{3}\left(\mathrm{PO}_{4}\right)_{2}$ and $\mathrm{SiO}_{2}$. Tricalcium phosphate was normally used as the source of $\mathrm{P}_{2} \mathrm{O}_{5}$. Samples of glass for subsequent heat treatment were made by melting batches of approximately $100 \mathrm{~g}$ in platinum crucibles at a temperature of $1400-1430^{\circ} \mathrm{C}$. After maintaining the molten state for about $1 \mathrm{~h}$, samples of glass were poured onto a stainless steel plate and then quenched at room temperature. Glass samples were subjected to heat treatment in the temperature range $700-800^{\circ} \mathrm{C}$ for the formation of nuclei and $850-950^{\circ} \mathrm{C}$ for the development of crystals.

\section{Measurement of mechanical properties}

In the compressive mode, a parallel cylinder of the material was machined and an external load applied so that the specimen was, macroscopically, in a state of uniaxial stress. 'The height/diameter ratio was lower than a critical value in order to eliminate the possibility of instability (buckling). Due to the aniso- 


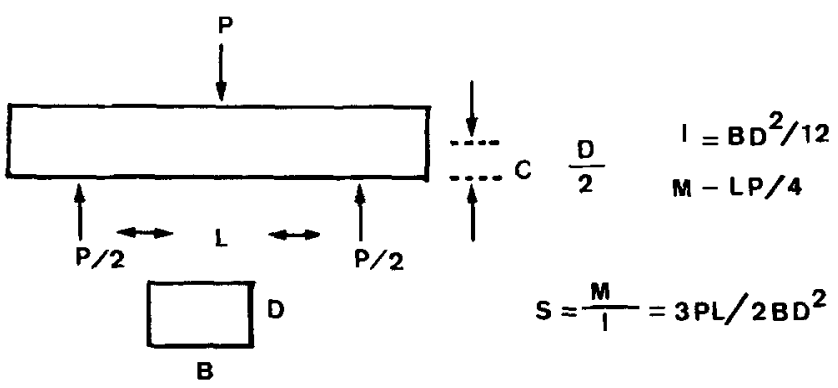

Figure 1 Scheme of the three-point bend test. The fixture should be set up so that the line of action of the applied load passes midway between the support roll centre for three-point loading

tropy of the individual grains, the state of stress is not uniaxial at the microscopic level; stress and strain inhomogeneities establish themselves inside the individual grains. However, in the treatment given here, these localized variations were not considered ${ }^{7}$.

Bending strength was measured by a three-point loading method using rectangular specimens $5 \times 5 \times$ $40 \mathrm{~mm}$ abraded with alumina powder and diamond paste. The span length was $32 \mathrm{~mm}$ and a cross-head speed of $0.5 \mathrm{~mm} \mathrm{~min}^{-1}$ was used at room temperature. The three-point bending strength, $S$, was calculated as the following equation:

$S=[3 P L] /\left[2 b d^{2}\right]$

where $P$ is the load to fracture the specimen, $L$ is the span length and the other symbols are geometrical values given in Figure 1 . Ten specimens were prepared for each condition to measure the three-point bending strength ${ }^{17}$.

\section{Specimen characterization}

The specimens were characterized by means of a number of techniques including $\mathrm{X}$-ray diffraction, scanning electron microscopy, optical microscopy and differential thermal analysis. Microscopic examinations were performed on polished samples which had been etched with $2 \% \mathrm{HF}$ for $15 \mathrm{~s}$. The samples examined in the scanning electron microscope were coated with a thin film of gold after etching. The kind and content of crystals precipitated in the samples were determined by powder X-ray analysis. Differential thermal analysis (DTA) of the specimen was employed to design the annealing temperature, crystallization temperature and heating schedule. Alumina powder was the reference material during the thermal history performed. An optical fluorescent microscope was used for new bone structure observation.

\section{Test animals and operating method}

Thirty experimental New Zealand rabbits obtained from local breeders were used as test animals. The average age of the test animals was 3 months. All the rabbits were male and had an average weight of $3 \mathrm{~kg}$. They were delivered to the laboratory not later than 1 week before the start of the test, and acclimatized to the housing conditions, tap water and the standard dry feed diet ${ }^{7,18,19}$.

The operations were carried out in a conventional operating theatre with the animals lying supine on an operating table. They were anaesthetized with a mask and semi-open system. After shaving, disinfection and sterile draping of the operation site, the femoral condyles were exposed by means of a medial longitudinal incision. A defect was created on the lateral femoral condyle with a $6 \mathrm{~mm}$ drill. All the holes were carefully rinsed and cleaned with Ringer's solution so that any abraded particles formed during drilling were removed. These defects were then completely filled with the implant material. The periosteum and skin were sutured with biodegradable thread. After operation, intramuscular injection of Keflin was used in order to reduce the possibility of infection.

The animals were later killed. The undecalcified bone histological technique was used in the research work because it concerned glass ceramics. The implanted areas were sectioned and soaked in a graded alcohol series for $24 \mathrm{~h}$ in each solution in order thoroughly to dehydrate and extract lipid. This is essential for the polymer to penetrate into the bone specimen completely. After being embedded, the specimens were sectioned for both scanning electron and optical microscopic observation.

\section{RESULTS AND DISCUSSION}

\section{Nucleation process}

The object of the heat-treatment process for glass is to convert the glass into a microcrystalline ceramic having properties superior to those of the original glass. It is especially important to achieve high mechanical strength and, since this is favoured by a fine-grained microstructure, the aim is to produce a glass-ceramic containing crystals of small dimensions which are closely interlocked. The production of large numbers of small crystals rather than a smaller number of relatively coarse crystals poses the requirement for efficient nucleation and this in turn means that careful control must be exercised over the nucleation stage of the heat treatment. Having nucleated the glass, it is necessary to raise the temperature further in order to permit crystal growth upon the nuclei $^{20}$. The optimum nucleation temperature generally seems to lie within the range of temperature corresponding to viscosities of $10^{11}$ to $10^{12}$ poises. The temperature within this range which gives optimum nucleation is determined by experimentation. As a first approximation, the optimum nucleation temperature lies between the softening point $(\mathrm{Mg}$ point) and a temperature $50^{\circ} \mathrm{C}$ higher than this ${ }^{21,22}$.

Figure 2 shows the result of a dilatometer test, which indicated that the $\mathrm{Mg}$ point of the glass was around $760^{\circ} \mathrm{C}$. Figure 3 summarizes the results of nucleation study on the glass under different heattreatment conditions. For this composition, there is a clearly defined nucleation condition of about $810^{\circ} \mathrm{C}$ for $50 \mathrm{~min}$. It is obvious that nucleation frequency initially increases with temperature up to $810^{\circ} \mathrm{C}$ but thereafter decreases (Figure 3). A general equation for the nucleation frequency proposed by StokesEinstein $^{23}$ gives a better approach. This expression is:

$I=v \mathrm{~N} \exp \left\{-\left[\Delta f_{\mathrm{a}}+\left(A / \Delta T^{2}\right)\right] / \mathrm{k} T\right\}$ 


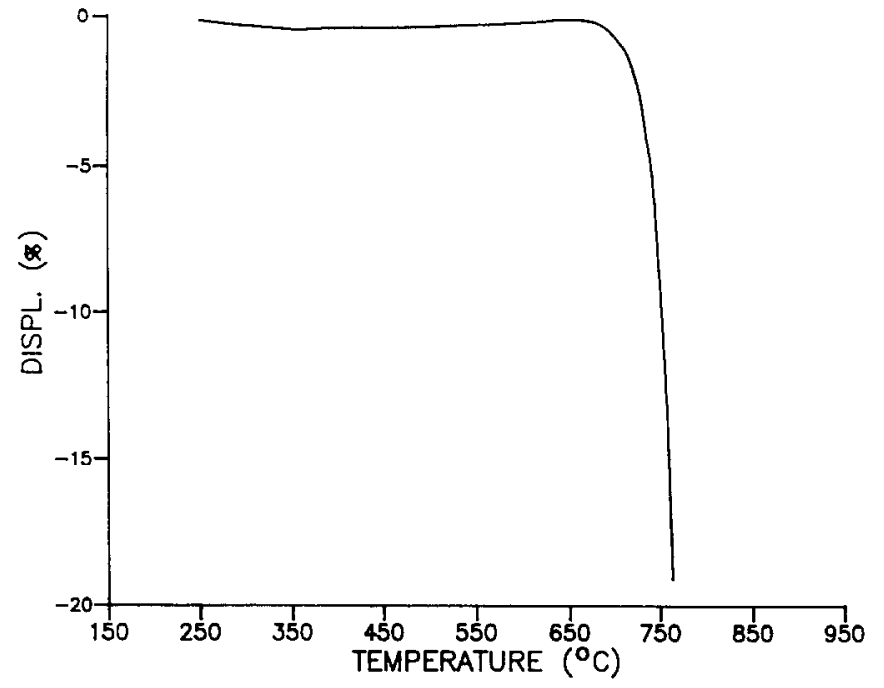

Figure 2 Dilatometer test for the bioglass measured at a rate of $39^{\circ} \mathrm{C}_{\text {min }^{-1}}$

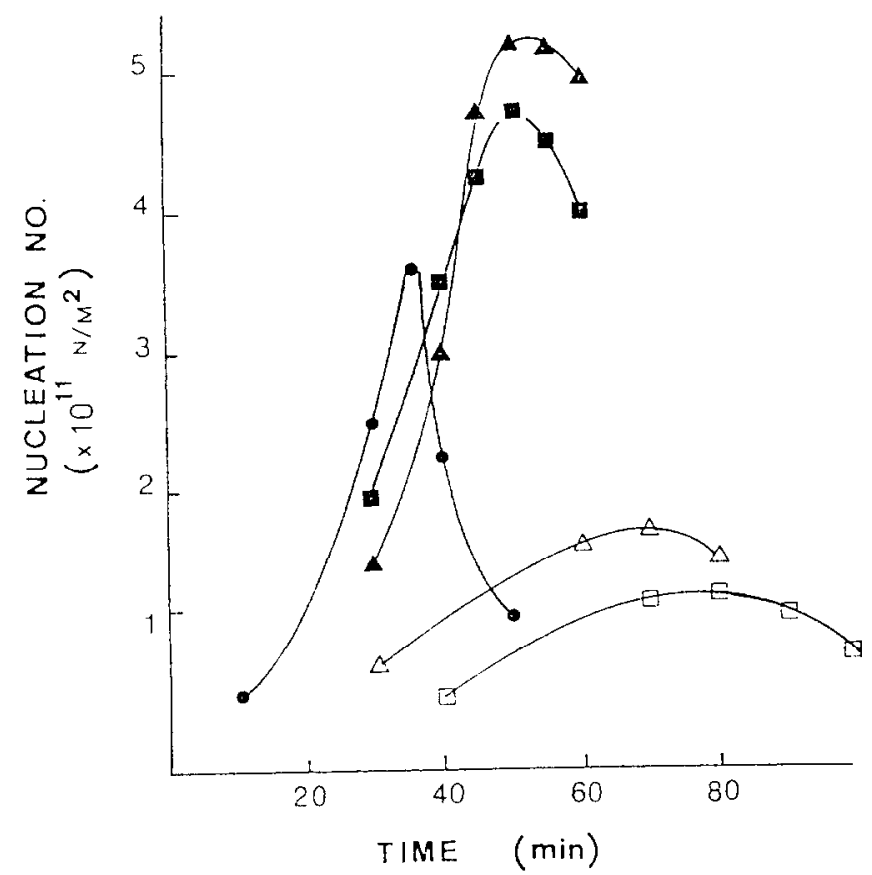

Figure 3 Nucleation density and holding time at different temperatures for the bioglass; $\square, 770^{\circ} \mathrm{C} ; \triangle, 790^{\circ} \mathrm{C} ; \boldsymbol{\square}, 800^{\circ} \mathrm{C} ; \boldsymbol{\Lambda}$, $810^{\circ} \mathrm{C}, 830^{\circ} \mathrm{C}$

where $I$ is the nucleation frequency and $v$ is the probability that an atom makes a successful jump. As written above the exponent has two terms which do not depend on the temperature in the same way. The first term, $\Delta f_{\mathrm{a}} / \mathrm{k} T$, represents the activation energy of the atom in the boundary jumping toward the nucleus. On the other hand, the behaviour of the second term, $A / \Delta T^{2} \mathrm{k} T$, which represents the driving force with the formation of a nucleus, is quite different. With decreasing temperature, this term falls and becomes much smaller than the first term. Since the nucleation frequency is controlled by the sum of these two terms, it has a maximum value where their sum is a minimum. In the present study, the driving force for the nucleation may increase at lower temperature; it might be expected that the nucleation will take place more rapidly. However, atomic mobility decreases very rapidly as temperature decreases, so that the sluggishness of the nucleation increases. As increasing temperature increases the atomic mobility, the driving force of the nucleation will be considerably less and may suppress the nucleation process. The net result is to have a maximum in the nucleation frequency of the glass at $810^{\circ} \mathrm{C}$ as observed experimentally and this is in agreement with the Stokes-Einstein equation.

Scanning electron micrographs of the samples of maximum nucleation frequency are shown in Figure 4. The droplet of glass as shown in Figure $4 a$ was rapidly reheated to observe the nucleus in detail. This procedure provided a means of easy counting of the number of nuclei under microscopic examination. Figure $4 b$ shows the microstructure after reheating of the droplet glass, so that the nucleation frequency could be measured under microscopic observation.

From the viewpoint of microstructure and mechanical property, it is found that $810^{\circ} \mathrm{C}$ for $50-60 \mathrm{~min}$ is a good condition for nucleation of the bioglass.

\section{Nucleation agent}

As mentioned in the previous section, the biocompatibility of the implant material is of considerable concern because it might contaminate the environment of the body. Material contact with bony tissue should not cause thrombus formation, adverse immune response or destroy cellular tissue etc. ${ }^{5,7}$. In our study, for the sake of biocompatibility, no
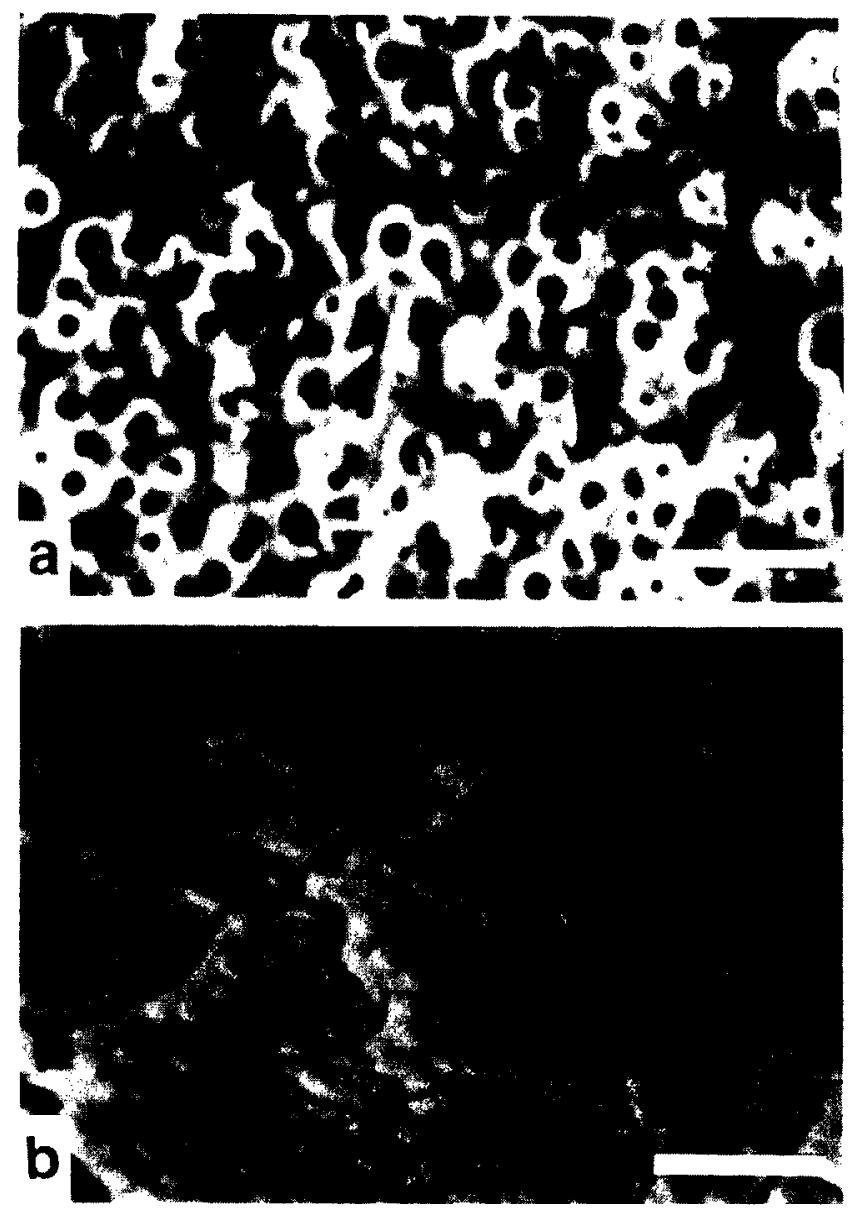

Figure 4 Scanning electron micrographs of the bioglass: a, nucleated at $810^{\circ} \mathrm{C}$ for $60 \mathrm{~min}$; bar, $5 \mu \mathrm{m}$; b, crystallized at $890^{\circ} \mathrm{C}$ for $10 \mathrm{~min}$; bar, $2 \mu \mathrm{m}$ 
additives such as $\mathrm{V}_{2} \mathrm{O}_{5}, \mathrm{TiO}_{2}, \mathrm{SnO}_{2}, \ldots$, were used as nucleation agents. But high nucleation frequency of the glass was observed, as shown in Figure 4a.

The network of a silicate glass is built up of $\mathrm{SiO}_{4}$ tetrahedral and this can incorporate 'foreign' structural units (either tetrahedral or triangle) to develop a composite network structure. The basic reason for incompatibility between different types of network structural groups is that differences between the charge of the principal network-forming ion (silicon) and that of other ions (phosphorus) which assume a network-forming position can lead to instability. McMillan and Partrige ${ }^{24}$ suggested that the phosphorus ion, $\mathrm{P}^{+5}$, was in a tetrahedral condition and therefore provided a phase separation which was due to a charge difference between the principal networkforming ions, $\mathrm{Si}^{+4}$, and 'foreign' network-forming ions, $\mathbf{P}^{+5}$. If the phosphorus-oxygen bonds were all single bond of the $\mathrm{P}-\mathrm{O}$ type, electroneutrality could not be satisfied so that one phosphorus-oxygen bond in tetrahedral $\mathrm{PO}_{4}$ would have to be a double bond. The presence of a double-bonded oxygen ion within the silicate network creates a condition favouring the separation of the phosphate grouping from the silicate network. In such a case, the equilibrium would be formed in the melt condition, and the phosphorus tetrahedral unit would be compatible with the silicate network. However, since tetrahedral units containing the pentavalent ion would disturb the bonding in the silicate network, phase separation would occur during reheating of the quenched glass.

Under these circumstances, it appears that the glass containing $\mathrm{P}_{2} \mathrm{O}_{5}$ might lead to glass-in-glass phase separation as a nucleation agent in the glass. Therefore, the materials present a high nucleation frequency which might result in a fine and uniform grained microstructure.

\section{Crystallization and mechanical strength}

The mechanical strength of a bone graft is one of its most important properties since it is often the major

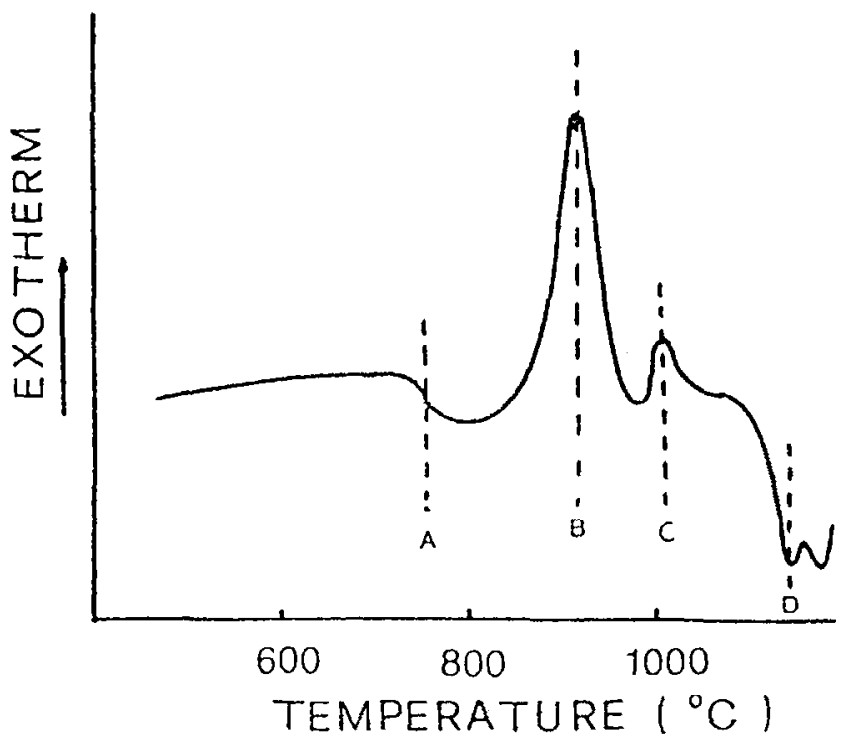

Figure 5 DTA curve of the bioglass powder: $A=$ annealing point; $B=$ exothermal peak due to formation of crystal; $C=$ exothermic peak for grain growth; $\mathrm{D}=$ endothermic peak due to melting

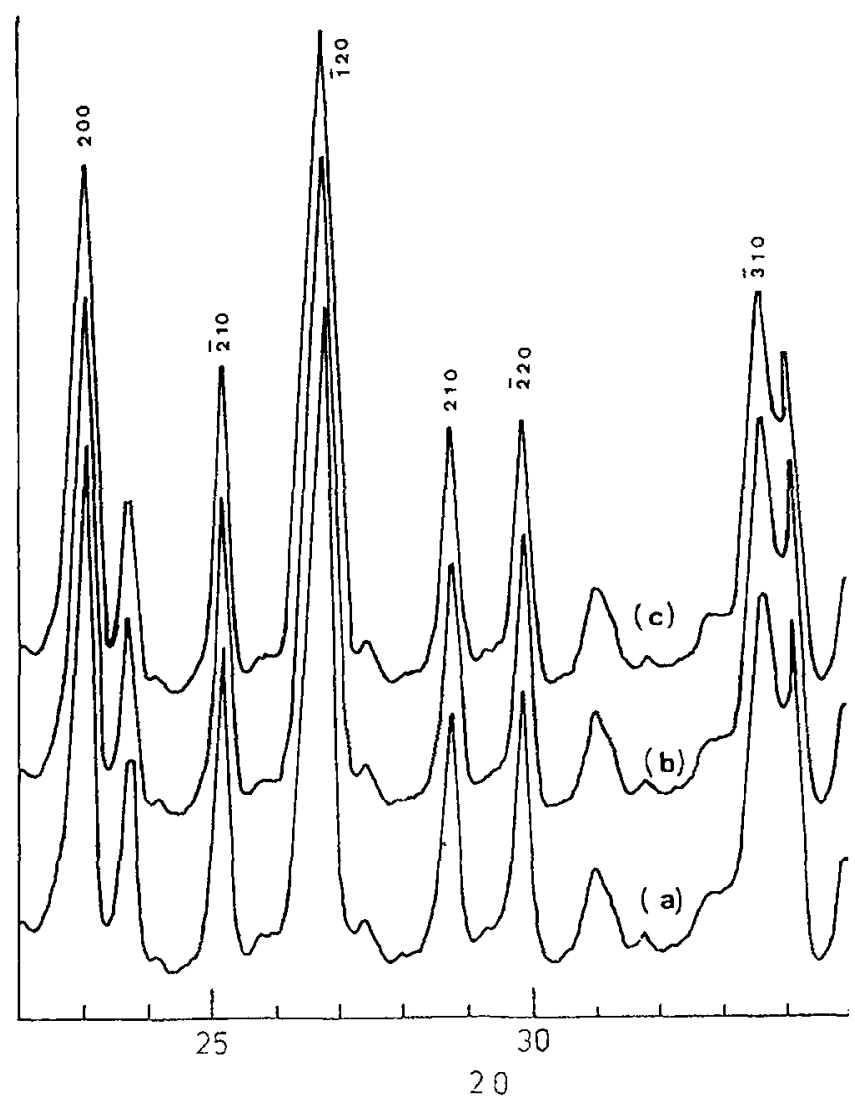

Figure 6 Results of $\mathrm{X}$-ray diffraction analysis of the bioglass heated at a, $890^{\circ} \mathrm{C} ; \mathrm{b}, 990^{\circ} \mathrm{C} ; \mathrm{c}, 1050^{\circ} \mathrm{C}$ for $2 \mathrm{~h}$

factor in determining the suitability of the material for a particular application. A typical DTA curve is shown in Figure 5. During the heating of the glass powder, the samples were taken out at different temperatures for X-ray diffraction study. It could be observed that the glass was crystallized at $890^{\circ} \mathrm{C}$ and identified as the phase of $(\mathrm{Na}, \mathrm{Ca})(\mathrm{P}, \mathrm{Si}) \mathrm{O}_{3}$. When the temperature was raised to $1050^{\circ} \mathrm{C}$, an exothermic reaction was revealed which was thought to be drastic grain growth of $(\mathrm{Na}, \mathrm{Ca})(\mathrm{P}, \mathrm{Si}) \mathrm{O}_{3}$ [Ref. 19]. The results of $X$-ray diffraction analysis for annealing at different temperature of $2 \mathrm{~h}$ duration are shown in Figure 6 . In our study, the crystallization temperature of the glass was chosen to be $890^{\circ} \mathrm{C}$ because of microstructural mechanical strength considerations.

Specimens were given a nucleation treatment for $50 \mathrm{~min}$ at $810^{\circ} \mathrm{C}$ followed by treatment at $890^{\circ} \mathrm{C}$ for periods of $10-70 \mathrm{~min}$ to accomplish crystallization. The three-point bending strength and compressive strength varying with crystallization time of the glass ceramics are shown in Figure 7. It was found that the better crystallization time of the glass at $890^{\circ} \mathrm{C}$ was $50 \mathrm{~min}$ as far as the mechanical properties were concerned. Three-point bending strength and compressive strength were $160-190 \mathrm{MPa}$ and $800-900 \mathrm{MPa}$, respectively. If the crystallization time of the glass is longer or shorter than $50 \mathrm{~min}$, the mechanical strength of the glass ceramics is lowered. It is believed that the mechanical strength of the glass ceramics is strongly controlled by the mean grain diameter and the mean free path (which is related to the content of residual glass in the glass ceramics). Utsumi and Sakka ${ }^{25}$ suggested that the mechanical 

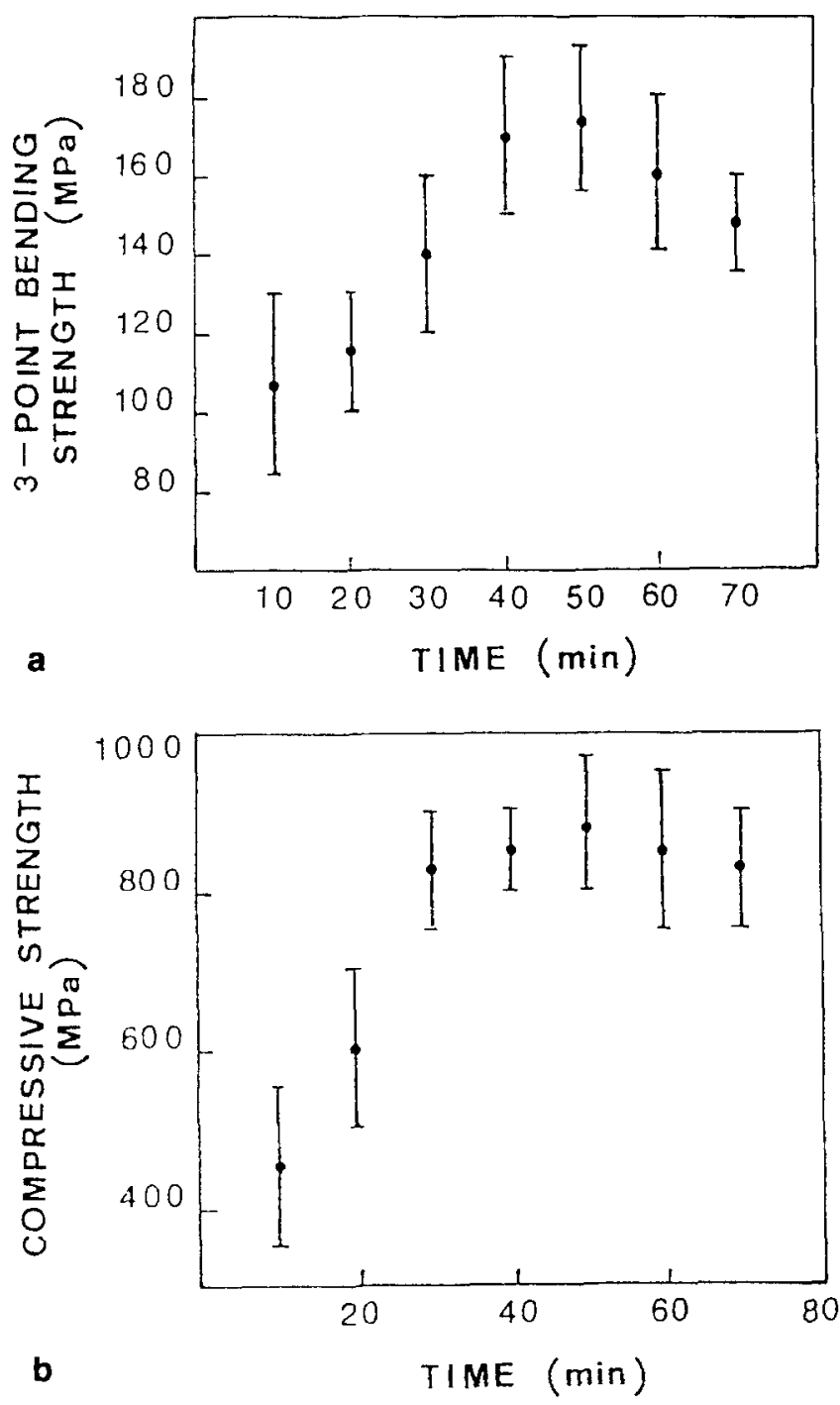

Figure 7 Relationship between mechanical strength and crystallization time of the bioglass ceramics: $\mathbf{a}$, three-point bending strength; $\mathbf{b}$, compressive strength

strength of a glass ceramic is inversely proportional to the mean grain diameter and mean free path. In an earlier report ${ }^{16}$, the mean grain diameter of the glass ceramic increased with crystallization time that would lead to mechanical strength decrease. The longer crystallization time decreased the content of residual glass in the glass ceramics, decreased the mean free path and increased the mechanical strength. Thus, the mechanical strength of the glass ceramics, as shown in Figure 7 , increased with crystallization time up to $50 \mathrm{~min}$ but decreased thereafter.

After the glass had been nucleated at $810^{\circ} \mathrm{C}$ for $50 \mathrm{~min}$ and then crystallized at $890^{\circ} \mathrm{C}$ for $50 \mathrm{~min}$, the material shows a uniform grain size of about $10 \mu \mathrm{m}$ as shown in Figure 8.

\section{Histological evaluation}

Thirty experimental rabbits were used in the study. Five were sacrificed at $2,4,8,12,16$ and 32 weeks after being implanted; having been implanted for 12 weeks, the material was totally surrounded by new bone. The bonding area between the material and new bone was increased with the implantation

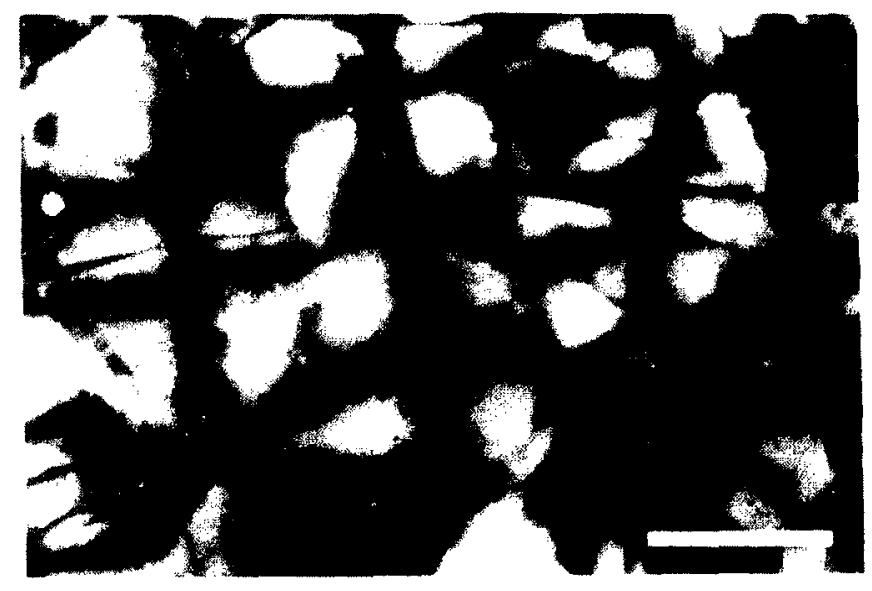

Figure 8 Optical micrograph of the bioglass ceramics nucleated at $810^{\circ} \mathrm{C}$ for $50 \mathrm{~min}$ and crystallized at $890^{\circ} \mathrm{C}$ for $50 \mathrm{~min}$; bar, $15 \mu \mathrm{m}$

period. The material would be directly connected with new bone without any connective tissue after 16 weeks' implantation. Detailed discussion around this field will be reported elsewhere.

Figure 9 is an X-ray photograph of a rabbit condyle where an implant is indicated by a heavy arrow. The results of the animal studies are encouraging. The rabbits recovered very soon after implantation and their tissue was not allergically sensitized. No inflammation or pathological disease was discovered. After implantation for two months, the space between implant and surrounding bone was filled with fibrous tissue or replaced by newly formed bony tissue. Figure $10 a$ shows that the glass ceramics are covered by regenerated bone indicating intensive bone regeneration. From the fluorescence microscopic examination, the old bony tissue and regenerated bony tissue can be distinguished through the staining process. As shown in Figure 10b, tetracycline and calcine green could deposit in the new bone area, and the new bone formation could be easily observed under the fluorescence microscope. The glass ceramics used in this study induced the new osteous tissue to form a tight chemical bond to the implant, intimately associated with the biological texture. No osteoclastic reactions, cell necrosis or inflammation were observed.

The material appeared to have a number of advantages over allografts and xenografts. These include biocompatibility, availability in quantity

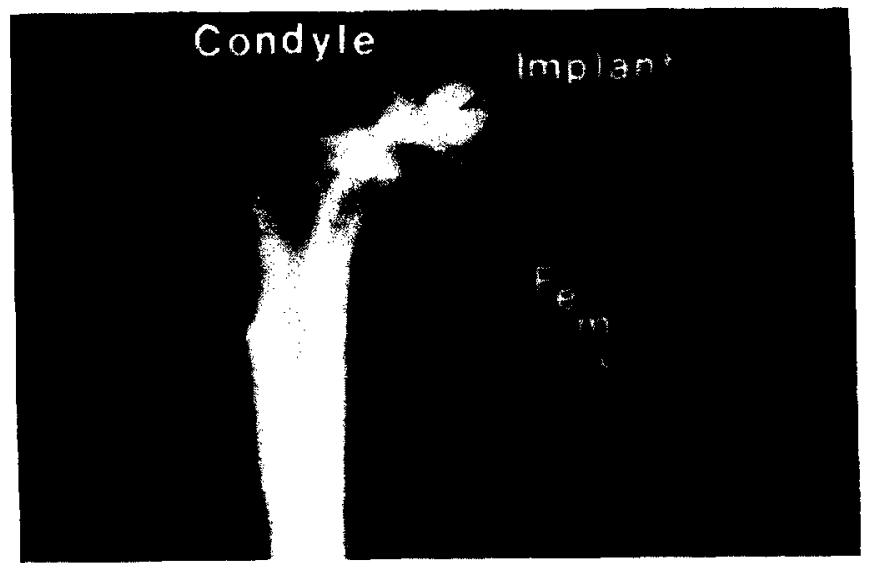

Figure 9 X-ray photograph of the bioglass ceramics implanted in the rabbit condyle 

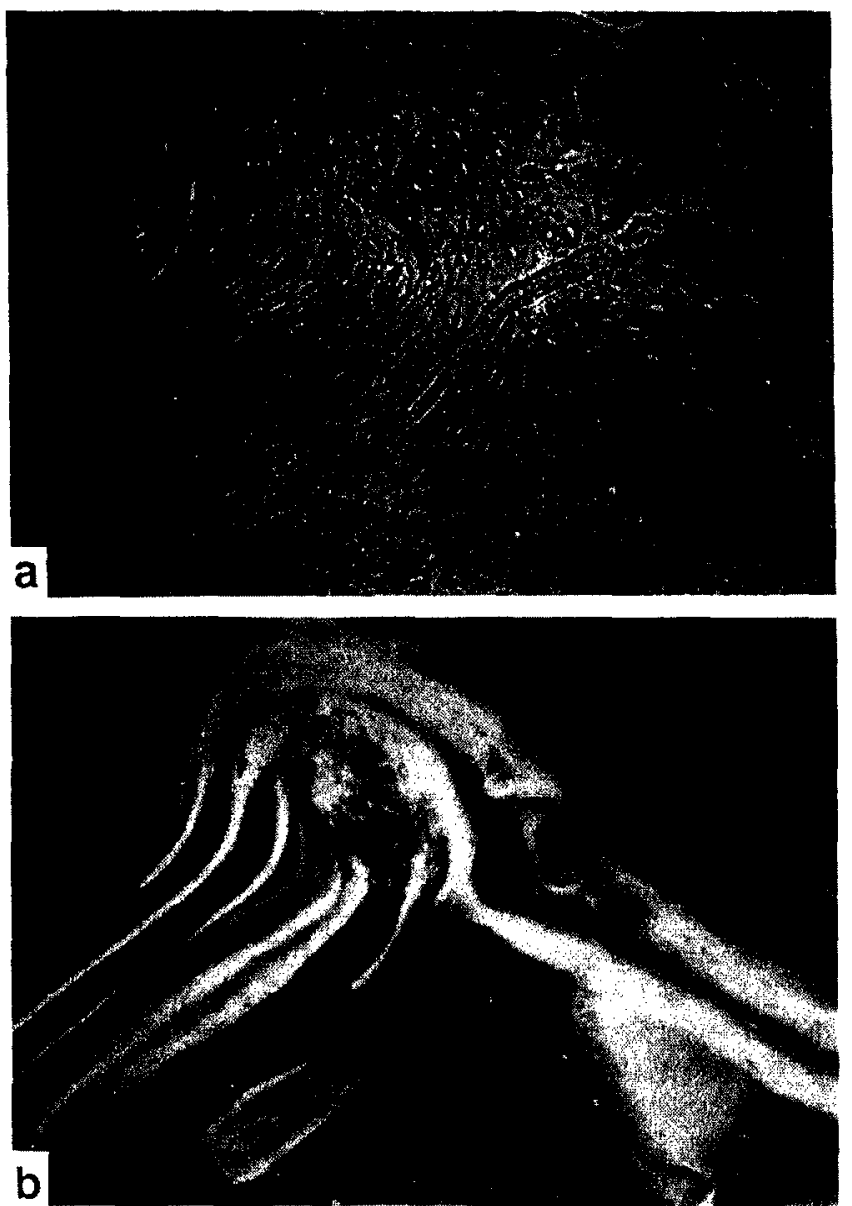

Figure 10 Optical microscopic observation of the bioglass after 2 months implanted: $a$, the material is completely embedded in regeneration bone; there is no separating layer of connective tissue; osteocytes can be detected on the surface of the material; $\mathbf{b}$, bone regeneration can be seen in direct contact with the implanted material under fluorescence microscopic examination. IM: implant; NBA: new bone area; CG: calcine green; TC: tetracycline; OB: old bone

required, ease of incorporation, ease of sterilization with no risk of disease transfer, lack of immunological problems, etc. Allografts are of known efficiency and have osteogenic capacity but the material as mentioned above could theoretically be a useful adjunct.

\section{CONCLUSIONS}

The glass ceramics with weight percentage of $\mathrm{Na}_{2} \mathrm{O}$ $8.4 \%, \mathrm{CaO} 40.6 \%, \mathrm{P}_{2} \mathrm{O}_{5} 12 \%$ and $\mathrm{SiO}_{2} 39 \%$ revealed a high nucleation density which may be due to the glass-in-glass separation of $\mathrm{P}_{2} \mathrm{O}_{5}$ contained in the material. After nucleation at $810^{\circ} \mathrm{C}$ for $50 \mathrm{~min}$ and crystallization at $890^{\circ} \mathrm{C}$ for $50 \mathrm{~min}$, the glass ceramics had a fine and uniform grained microstructure and exhibited fairly high mechanical strength.

The material used in this experiment showed no inflammation and no toxic substances released. The implant also showed tight chemical bonding with biological tissue.

\section{REFERENCES}

1. Aebi M, Regazzoni P. Bone Transplantation, Up-dating on Osteochondral Auto- and Allografting. Berlin/Heidelberg/ New York/Tokyo: Springer, 1987.

2. Albrektsson T, Lindner L. Intravital, long-term follow-up of autologous experimental bone grafts. Arch Orthop Traumat Surg 1981; 98: 189-92.

3. Brown KLB, Cruess RL. Bone and cartilage transplantation in orthopaedic surgery. J Bone Joint Surg Am 1982; 2: $270-9$.

4. Amler MH, LeGeros RZ. Hard tissue replacement polymer as an implant material. J Biomed Mater Res 1990; 24: 1079-89.

5. Katthangen BD, Mittelmeier $\mathrm{H}$. Experimental animal investigation of bone regeneration with collagen apatite. Arch Orthop Trauma Surg 1984; 103: 291-6.

6. Lowe J, Stein H, Sela J. Primary calcification in remodeling haverian systems following tibial fracture in rats. Clin Orthop 1983; 176: 291-7.

7. Lin FH, Hon MH. A study on synthesized hydroxyapatite bioceramics. Ceram International 1989; 15: 351-6.

8. Peelen JGJ, Rejda BV, Vermeiden JPW, de Groot K. Sintered tricalciumphosphate as bioceramics. Sci Ceram 1977; 9: 226-32.

9. Jarcho M. Calcium phosphate as hard tissue prosthetics. Clin Orthop Relat Res 1981; 157: 259-78.

10. Hench LL. The interfacial behavior of biomaterials. J Biomed Mater Res 1980; 14: 803-9.

11. Hench LL. Ceramic implants. Glass Ceram Bull 1975; 22: $82-6$.

12. Hench LL, Splinter RJ, Allen C, Greenle TK. Bonding mechanisms at interface of ceramic prosthetics materials. J Biomed Mater Res 1971; 2: 117-22.

13. Blencke BA, Bromer H, Deutscher K. Glass ceramics bioactive implants. Med Orthop Techn 1975; 95: 144-50.

14. Eulenberger J, Stich H, Niederer PG. Biokeramik im Rattenversuch. Scheweiz Monatsschr Zahnkeilkd 1978; 88: 378-82.

15. Kokubo T, Kushitani H, Sakka S, Kitsugi T, Yamamuro T. Solutions able to reproduce in vivo surface structure changes in bioactive glass-ceramic A-W. J Biomed Mater Res 1990; 24: 721-34.

16. Lin $\mathrm{FH}, \mathrm{Hon} \mathrm{MH}$. A study on bioglass ceramics in the $\mathrm{NaO}-\mathrm{CaO}-\mathrm{PO}-\mathrm{SiO}$ system. J Mater Sci 1988; 23: 4295-9.

17. Meyers MA, Chawla KK. Mechanical Metallurgy-Principles and Applications. Englewood Cliffs, NJ: Prentice-Hall, 1984.

18. Termine JD. Mineral chemistry and skeletal biology. Clin Orthop 1972; 85: 207-12.

19. Lin FH, Hon MH. Crystallography and crystal growth of the $(\mathrm{Na}, \mathrm{Ca})(\mathrm{P}, \mathrm{Si}) \mathrm{O}_{3}$ compound. J Crystal Growth 1989 ; 94: $357-64$

20. Turnbull D, Cech RE. The growth of crystals and the equilibrium structures of their surface. $J$ Appl Phys 1950; 21: 804-11.

21. Ublman DK. Advance in nucleation and crystallization in glasses. J Am Ceram Soc 1971; 31: 91-9.

22. Valverde V, Wagner C. Consideration on the kinetics and mechanisms of the dissolution of metal oxides. Phys Chem $1976 ; 80: 330-8$

23. Tamman G. The mechanism of the dissolution of silica in acid mixtures. J Am Ceram Soc 1947; 30: 165-70 (2nd edn).

24. McMillan PW. Glass-ceramics. New York: Academic Press, 1979. Ch. 2, pp 7-38.

25. Utsumi Y, Sakka S. Mechanical properties of glass and glass ceramics. J Am Ceram Soc 1970; 53: 286-92. 